\title{
A novel method to depurate $\beta$-lactam antibiotic residues by administration of a broad-spectrum $\beta$-lactamase enzyme in fish tissues
}

\author{
Young-Sik Choe, Ji-Hoon Lee, Soo-Geun Jo and Kwan Ha Park ${ }^{*}$
}

\begin{abstract}
As a novel strategy to remove $\beta$-lactam antibiotic residues from fish tissues, utilization of $\beta$-lactamase, enzyme that normally degrades $\beta$-lactam structure-containing drugs, was explored. The enzyme (TEM-52) selectively degraded $\beta$-lactam antibiotics but was completely inactive against tetracycline-, quinolone-, macrolide-, or aminoglycosidestructured antibacterials. After simultaneous administration of the enzyme with cefazolin (a $\beta$-lactam antibiotic) to the carp, significantly lowered tissue cefazolin levels were observed. It was confirmed that the enzyme successfully reached the general circulation after intraperitoneal administration, as the carp serum obtained after enzyme injection could also degrade cefazolin ex vivo. These results suggest that antibiotics-degrading enzymes can be good candidates for antibiotic residue depuration.
\end{abstract}

Keywords: $\beta$-Lactamase, Carp, Antibiotics, Depuration

\section{Background}

Concerns have risen over the presence of antimicrobial residues in food fishes because the contaminants can cause human pathogenic bacteria to develop resistance to therapeutically valuable antimicrobials (Cabello, 2006). Development of antibacterial resistance will then require higher doses of the same agent, or more potent drugs for efficacious treatment of bacterial pathogens. Of several known mechanisms for resistance development, degradation of antimicrobial agents is regarded as the most frequent one (De Pascale and Wright 2010).

Soon after the introduction of $\beta$-lactam antibiotics such as penicillins and cephalaosporins into clinical use, bacterial resistance to these drugs were reported (Abraham and Chain, 1988). Those bacteria have been found to harbor plasmid-borne genes producing enzymes which can catalyze a few $\beta$-lactam antibiotics nullifying the efficacy of such drugs (Matagne et al. 1999). However, the efficacy has become increasingly

\footnotetext{
*Correspondence: khpark@kunsan.ac.kr

Department of Aquatic Life Medicine, College of Ocean Sciences, Kunsan National University, San-68 Miryong-Dong, Gunsan City, Jeonbuk, South Korea
}

(c) The Author(s). 2016 Open Access This article is distributed under the terms of the Creative Commons Attribution 4.0 International License (http://creativecommons.org/licenses/by/4.0/), which permits unrestricted use, distribution, and reproduction in any medium, provided you give appropriate credit to the original author(s) and the source, provide a link to the Creative Commons license, and indicate if changes were made. The Creative Commons Public Domain Dedication waiver (http://creativecommons.org/publicdomain/zero/1.0/) applies to the data made available in this article, unless otherwise stated. limited by the advent of $\beta$-lactamase that catalyzes a broader range of $\beta$-lactam antibiotics compared with previous enzymes (Livermore 1995). Those enzymes are called extended-spectrum $\beta$-lactamase (ESBL) and they are usually represented by TEM-52.

If $\beta$-lactamase can catalyze $\beta$-lactam antibiotics in fish tissues, it could be useful to remove residual antibiotics remaining after use to food fish species. To test this possibility, we assessed the catalytic activity in vitro of purified TEM-52 enzymes obtained by recombinant DNA techniques, followed by an in vivo activity test in carp after administration of cefazolin, a $\beta$-lactam antibiotic.

\section{Methods}

$\beta$-Lactamase enzyme preparations

The gene for TEM-52 was obtained from a Korean clinical isolate after necessary cloning processes (Pai et al., 1999). Its sequence was confirmed to match $100 \%$ by query coverage tests with those of extended-spectrum enzymes reported from Salmonella enterica subspp. enterica serovar Typhimurium (gb|AY883411.1|) and Klebsiella pneumoniae (emb|Y13612.1). This gene was used to build a recombinant plasmid and inserted into E. coli 
and then cultured at $30{ }^{\circ} \mathrm{C}$ for about $48 \mathrm{~h}$ in $2-\mathrm{L}$ complex media. When the culture reached the density of ca. 0.7 optical density at $650 \mathrm{~nm}$, cells were harvested by centrifugation $\left(\times 13,000 g, 10 \mathrm{~min}, 3{ }^{\circ} \mathrm{C}\right)$. Cells were disrupted by sonication and the lysate was processed for purification purposes with Q-Sepharose FF column chromatography after refolding steps. The refolding process was composed of decreasingly stepwise dilutions at $8,2,1$, and $0.4 \mathrm{M}$ in denaturant urea. The TEM-52 enzyme was eluted in $20 \mathrm{mM}$ Tris buffer (pH 7.0) and adjusted to contain $500 \mathrm{mU} / \mathrm{ml} \beta$-lactamase activity when assayed for $5 \mathrm{~min}$ using nitrocefin $(50 \mu \mathrm{g} /$ $\mathrm{ml}$, Oxoid, Basingstoke, UK) as the substrate (O'Callaghan et al., 1972). The final purified TEM-52 enzyme is known to have a molecular mass of $28 \mathrm{KDa}$ (Perilli et al., 2002).

\section{In vitro degradation activities against various antimicrobials}

Degradation activity of TEM-52 against various classes of antimicrobials was assessed incubating the $\beta$-lactamase enzyme solution $(25 \mathrm{mU} / \mathrm{ml})$ with various antimicrobials. Ten different antimicrobials (cefotaxime-Na, cefazolin$\mathrm{Na}$, penicillin-G-K salt, amoxicillin, pivampicillin, oxytetracycline- $\mathrm{HCl}$, ciprofloxacin, erythromycin, josamycin, and streptomycin) were incubated with TEM-52 in $50 \mathrm{mM}$ sodium phosphate buffer $(\mathrm{pH} 7.0)$ for $30 \mathrm{~min}$ at $25{ }^{\circ} \mathrm{C}$, and then followed by bioassay for semi-quantitative analysis of remaining drug levels. These antimicrobials were obtained from Sigma (St. Louis, MO, USA) except pivampicillin (Dong-Hwa Pharmaceuticals, Seoul, Korea) and josamycin (Wako Chemicals, Japan). Paper disks (8 mm diameter, Advantec Toyo, Dublin, CA, USA) were soaked with $50 \mu \mathrm{l}$ of incubated enzyme-antimicrobial mixtures and placed on top of BHI agar in Petri dishes streaked with Staphylococcus epidermidis ATCC10145 (precultured in BHI to $1.8 \times 10^{7} \mathrm{CFU} / \mathrm{ml}$ ). The dishes were incubated at $36{ }^{\circ} \mathrm{C}$ for $12 \mathrm{~h}$, and inhibitory zones beyond the disk areas were measured.

In vivo and ex vivo degradation activities against cefazolin Of several $\beta$-lactam antibiotics, cefazolin was selected as the model antibiotic because of the simplicity in chemical analysis for both in vivo and ex vivo studies. To assess degradation activity of TEM-52 more quantitatively than the above in vitro study, cefazolin was incubated with TEM-52 $(25 \mathrm{mU} / \mathrm{ml}$ in $50 \mathrm{mM}$ phosphate buffer, $\mathrm{pH}$ 7.0) for $30 \mathrm{~min}$ and remaining concentration of cefazolin was chemically analyzed with a high-performance liquid chromatography (HPLC) method.

The HPLC-UV method for cefazolin analysis (Nadai et al., 1993) was composed of a Waters 2690 separation module and Waters 2487 dual wavelength UV-visible detector at $274 \mathrm{~nm}$ (Waters, Milford, MA, USA). Samples were injected into a $\mathrm{C}_{18}$ reverse-phase HPLC column
$(250 \times 4.6 \mathrm{~mm}, 5 \mu \mathrm{m}$ particle size, Shiseido, Japan) at 10-50 $\mu \mathrm{l}$ range and eluted with a mobile phase composed of $30 \mathrm{mM}$ sodium phosphate buffer $(\mathrm{pH} 5.0)$ and methanol (88:12 ratio). Flow rate of the mobile phase was $1.2 \mathrm{ml} / \mathrm{min}$.

For in vivo cefazolin degradation experiment, common carp Cyprinus carpio weighing 40-100 g maintained at $23{ }^{\circ} \mathrm{C}$ were used. Cefazolin (sodium salt, Sigma) was dissolved in sterile saline and administered intramuscularly (im) around the lateral line to render doses of 10 and $30 \mathrm{mg} / \mathrm{kg}$ of drug base. TEM-52 enzyme was immediately injected into the peritoneal cavity at $75 \mathrm{mU} / 100 \mathrm{~g}$ body weight. This intraperitoneal (ip) injection volume was $150 \mu \mathrm{l} / 100 \mathrm{~g}$ and an equivalent volume of saline was also administered to control fish. One hour after TEM-52 injections, fish were anesthetized with MS-222 (Sigma) and blood was sampled for cefazolin analysis through the caudal vessels. Serum was subsequently obtained following centrifugation at $\times 3600 \mathrm{~g}$ for $20 \mathrm{~min}$ under refrigeration $\left(3{ }^{\circ} \mathrm{C}\right)$. Liver and muscle were also isolated for cefazolin analyses. Serum and fish tissues were mixed with HPLC mobile phase in tenfold volumes and vigorously vortex-shaken before filtering through membrane filters, and finally injected into the HPLC column. This method led to an almost complete cefazolin recovery $(>90 \%, n=3)$. With cefazolin-spiked liver and muscle tissues (10, 20, 50, 100, and $200 \mathrm{ng} / \mathrm{g}$ ), linearity of the standard curve was confirmed $\left(r^{2}=\right.$ 0.967). The limits of detection (LOD) and quantification (LOQ) were 10 and $30 \mathrm{ng} / \mathrm{g}$, respectively.

In some fish, TEM-52 was administered into the peritoneal cavity (ip) at $75 \mathrm{mU} / 100 \mathrm{~g}$ to naive carp, and serum was obtained $1 \mathrm{~h}$ later to assess ex vivo degradation activity against cefazolin. All experiments using carp were performed in accordance with the guidelines approved by the Institutional Animal Care and Use Committee, Kunsan National University, Korea.

\section{Statistics}

Data were expressed as mean \pm S.D. Statistical significance was examined with unpaired $t$ tests at the significant level of $p<0.05$.

\section{Results and discussion}

Table 1 shows in vitro enzymatic activity of TEM-52 to degrade different classes of antibacterial agents. TEM-52 is a wide spectrum $\beta$-lactamase obtained from $E$. coli through recombinant DNA technique. The enzyme preparation reduced antibacterial activity of $\beta$-lactam antibiotics without effects on drugs of other classes, indicating highly selective degradation activity toward $\beta$-lactams. Other classes of antibacterials, i.e., tetracycline, quinolone, macrolide, and aminoglycoside, were not influenced at all. These data reflect that the enzyme preparation contains 
Table 1 Bioassay of degradation activity of TEM-52 enzyme against various classes of antimicrobials

\begin{tabular}{|c|c|c|c|}
\hline \multirow[t]{2}{*}{ Class } & \multirow[t]{2}{*}{ Antimicrobials } & \multicolumn{2}{|c|}{ Inhibition zone (mm, mean \pm SD) } \\
\hline & & Control drug disk & TEM-52-treated drug disk \\
\hline \multirow[t]{5}{*}{$\beta$-Lactam } & Cefotaxime & $9.3 \pm 0.6$ & $0.0 \pm 0.0$ \\
\hline & Cefazolin & $6.0 \pm 1.7$ & $2.3 \pm 1.2$ \\
\hline & Penicillin G & $8.0 \pm 0.6$ & $0.0 \pm 0.0$ \\
\hline & Amoxicillin & $8.7 \pm 0.6$ & $0.0 \pm 0.0$ \\
\hline & Pivampicillin & $7.3 \pm 0.6$ & $0.0 \pm 0.0$ \\
\hline Tetracycline & Oxytetracycline & $9.8 \pm 0.9$ & $9.7 \pm 0.6$ \\
\hline Quinolone & Ciprofloxacin & $8.2 \pm 0.0$ & $8.0 \pm 0.4$ \\
\hline \multirow[t]{2}{*}{ Macrolide } & Erythromycin & $10.0 \pm 1.0$ & $10.0 \pm 2.0$ \\
\hline & Josamycin & $8.6 \pm 0.6$ & $8.7 \pm 0.5$ \\
\hline Aminoglycoside & Streptomycin & $8.5 \pm 0.4$ & $8.7 \pm 0.6$ \\
\hline
\end{tabular}

Concentrations of antimicrobials in incubation were adjusted to produce $6-11 \mathrm{~mm}$ clear zones beyond the disk areas $(0.5-500 \mu \mathrm{g} / \mathrm{disk})$ Triplicate determinations
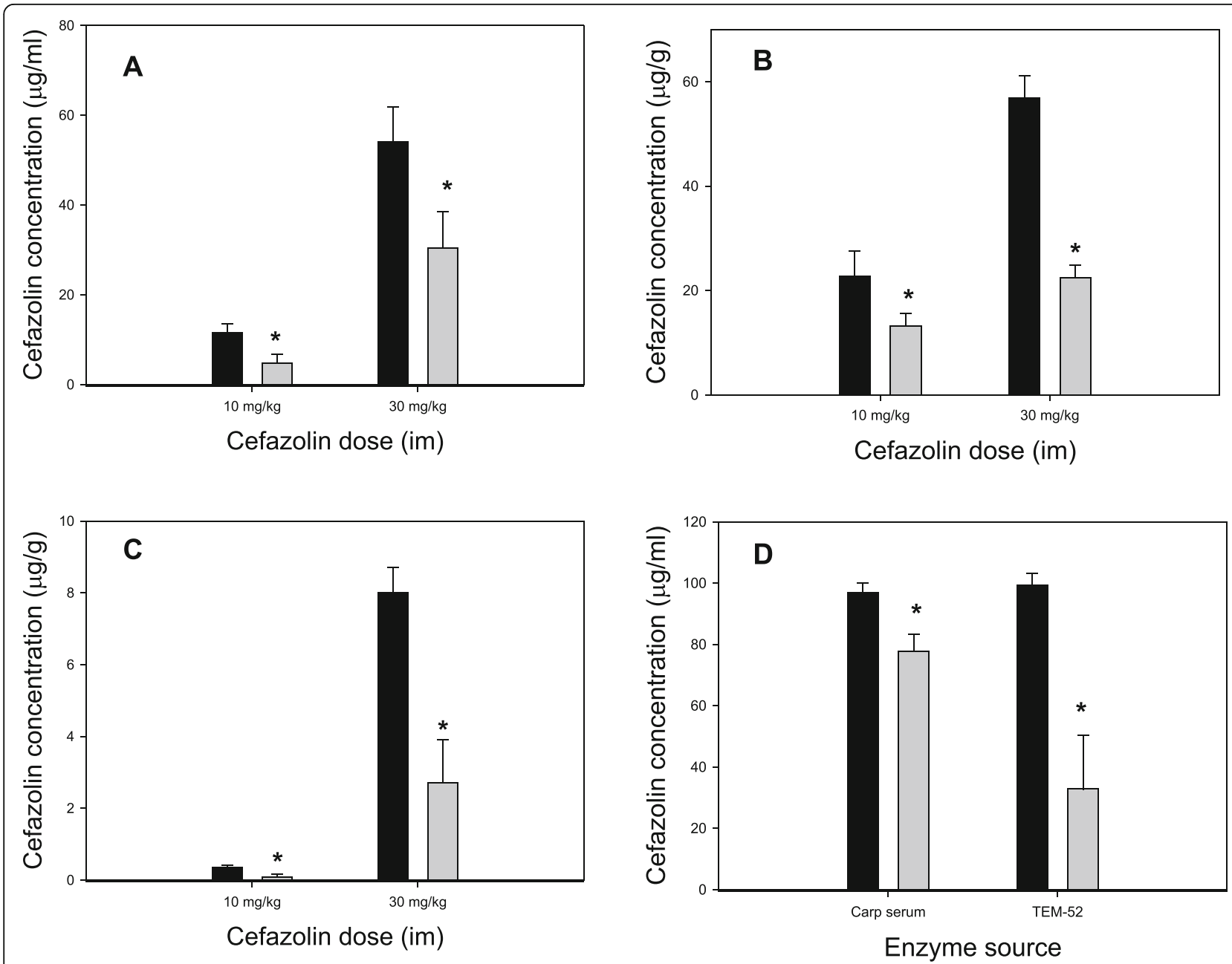

Fig. 1 In vivo and ex vivo cefazolin degradation activity of TEM-52 in carp. a-c In vivo cefazolin changes in serum (a), liver, (b) and muscle (c) following intraperitoneal injection of TEM-52, $N=5-10$; filled bar, control carp; shaded bar, TEM-52-injected carp (d) ex vivo cefazolin changes when TEM-52-injected carp serum were incubated with cefazolin, $N=5$; filled bar, without enzyme; shaded bar, incubated with TEM-52 itself or TEM-52-injected carp serum. ${ }^{*} \mathrm{p}<0.05$ with unpaired $t$ tests when compared to control groups 
exclusively $\beta$-lactamase efficacy and hydrolyzes $\beta$-lactams, cephalosporins, and penicillins (Bush et al., 1995; Pai et al., 1999; Poyart et al., 1998; Shahada et al., 2010), without any activity on other antibacterials.

Of the five $\beta$-lactam antibiotics examined with the in vitro bioassay, cefazolin was chosen for in vivo studies mostly because the procedures for HPLC analysis are quite simple. The results obtained after simultaneous administration of TEM-52 and cefazolin to carp are demonstrated in Fig. 1. In all three tissue samples examined, the levels of cefazolin were significantly lower in TEM52 co-administered fish compared with the cefazolinalone group. With cefazolin doses 10 and $30 \mathrm{mg} / \mathrm{kg}$, and regardless of tissues, the degree of reduction was $\sim 50 \%$ (Fig. 1a-c). In this in vivo experiment, TEM-52 was administered into the peritoneal cavity whereas cefazolin into the muscle. These results therefore indicate that $\beta$ lactamase activity included in TEM-52 and the $\beta$-lactam antibiotic cefazolin could come into direct contact in the fish body leading to cefazolin degradation. These results thus clearly demonstrate that TEM-52 is active not only in vitro system but also in the fish body, i.e., in vivo following injections.

It was additionally checked whether TEM-52 was actually present in carp serum after intraperitoneal injection to the fish. For this, TEM-52 was injected and serum was sampled $1 \mathrm{~h}$ later for ex vivo degradation tests. After incubation of TEM-52-pretreated carp serum with cefazolin ex vivo, a significant reduction $(p<0.05)$ in cefazolin residue was observed (Fig. 1d, Carp serum columns). In a parallel test, it was observed that if a higher reduction of cefazolin concentration occurred, cefazolin was incubated directly with TEM-52 in the presence of naive serum (Fig. 1d, TEN-52 columns). Although it is difficult to compare directly because these two test conditions were not identical, a significant portion of intact TEM-52 enzymes seemed to reach in serum when blood was taken ( $1 \mathrm{~h}$ post-injection).

Because TEM-52 was active for cefazolin degradation in carp, it can be deduced that the administered enzyme must have been sufficiently absorbed from the peritoneal cavity. It is not well described in fishes whether there is an inhibiting barrier to proteins injected into the peritoneal cavity. However, the fact that peptides are systemically active following intraperitoneal injection in fishes (Hong and Secombe, 2009; Murashita et al., 2010) suggests a loose barrier within the peritoneum in fishes. In rats too, absorption of proteins from the peritoneum is comparable to that of isotonic solution (Flessner, 2005).

\section{Conclusions}

In summary, this study is the first attempt to seek a utilization of sorts of antibiotics degradation enzymes to depurate drug residues in animals. We observed that
TEM-52, an enzyme active against a broad range of $\beta$ lactam antibiotics, can be a novel tool to remove residues from drug-treated fish bodies. It may be needed to expand tests against other $\beta$-lactam antibiotics and also in different fish species. There has not been any attempt in idea similar to this up to now. Various aspects of studies need to be carried out in order to establish practical usefulness. Safety of the test enzyme to humans is not known at all, for example.

Conclusively, however, a similar strategy will also be applicable to various classes of antimicrobials to which antibiotic-degrading enzymes have been reported.

\section{Acknowledgements}

This work was supported by the fund of Fisheries Research Institute of Kunsan National University in the year 2016. The authors are grateful for the production and supply of enzyme preparations to Dr. CS Shin at Advanced Protein Technologies Corp. (Gyeonggi Bio-center, Suwon, Korea) and Dr. SK Moon at MTC Korea (Gyeonggi Techno-Park, Ansan City, Gyeonggi-Do, Korea).

\section{Authors' contribution}

YSC carried out the in vitro and in vivo tests with the antimicrobials. JHL performed the HPLC analysis for the cefazolin residues. SGJ and KHP designed the overall experiments and prepared the manuscript. All authors read and approved the final manuscript.

\section{Competing interests}

The authors declare that they have no competing interests.

Received: 6 January 2016 Accepted: 2 December 2016

Published online: 22 December 2016

\section{References}

Abraham EP, Chain E. An enzyme from bacteria is able to destroy penicillin. 1940. Rev Infect Dis. 1988;10:677-8.

Bush K, Jacoby GA, Medeiros AA. A functional classification scheme for $\beta$ lactamases and its correlation with molecular structure. Antimicrob Agents Chemother. 1995;39:1211-33.

Cabello FC. Heavy use of prophylactic antibiotics in aquaculture: a growing problem for human and animal health and for the environment. Environ Microbiol. 2006:8:1137-44.

De Pascale G, Wright GD. Antibiotic resistance by enzyme inactivation: from mechanisms to solutions. Chem Biol Chem. 2010;11:1326-34.

Flessner MF. The transport barrier in intraperitoneal therapy. Am J Ren Physiol. 2005;288:F433-42.

Hong S, Secombe CJ. Two peptides derived from trout IL-1 $\beta$ have different stimulatory effects on immune gene expression after intraperitoneal administration. Comp Biochem Physiol Part B. 2009;153:275-80.

Livermore DM. $\beta$-lactamases in laboratory and clinical resistance. Clin Microbiol Rev. 1995:8:557-84

Matagne A, Dubus A, Galleni M, Frere JM. The beta-lactamase cycle: a tale of selective pressure and bacterial ingenuity. Nat Prod Rep. 1999;16:1-19.

Murashita K, Jordal AO, Nilsen TO, Stefansson SO, Kurokawa T, Björnsson BT, Moen AG, Rønnestad I. Leptin reduces Atlantic salmon growth through the entral pro-opiomelanocortin pathway. Comp Biochem Physiol Part A. 2010;158:79-86.

Nadai M, Hasegawa T, Kato K, Wang L, Nabeshima T, Kato N. Antimicrob Agents Chemother. 1993;37:1781-5.

O'Callaghan CH, Morris A, Kirby SM, Shingler AH. Novel method for detection of beta-lactamases by using a chromogenic cephalosporin substrate. Antimicrob Agents Chemother. 1972;4:283-8.

Pai H, Lyu S, Lee JH, Kim J, Kwon Y, Kim JW, Choe KW. Survey of extendedspectrum $\beta$-lactamases in clinical isolates of Escheria coli and Klebsiella pneumoniae: prevalence of TEM-52 in Korea. J Clin Microbiol. 1999;37:1758-63.

Perilli M, Segatore B, De Massis MR, Pagani L, Luzzaro F, Rossolini GM, Amicosante G. Biochemical characterization of TEM-92 extendedspectrum b-lactamase, a protein differing from TEM-52 in the signal peptide. Antimicrob Agent Chemother. 2002;46:3981-3. 
Poyart C, Mugnier P, Quesne G, Berche P, Trieu-Cuot P. A novel extendedspectrum TEM-type $\beta$-lactamse (TEM-52) associated with decreased susceptibility to moxalactam in Klebsiella pneumoniae. Antimicrob Agents Chemother. 1998:42:108-13.

Shahada F, Chuma T, Dahshan H, Akiba M, Sueyoshi M, Okamoto K. Detection and characterization of extend-spectrum $\beta$-latamase (TEM-52)-producing Salmonella serotype infantis from broilers in Japan. Foodborne Pathogens Dis. 2010;7:515-21.

Submit your next manuscript to BioMed Central and we will help you at every step:

- We accept pre-submission inquiries

- Our selector tool helps you to find the most relevant journal

- We provide round the clock customer support

- Convenient online submission

- Thorough peer review

- Inclusion in PubMed and all major indexing services

- Maximum visibility for your research

Submit your manuscript at www.biomedcentral.com/submit 